\title{
ENVIRONMENTAL PROBLEMS OF AGRICULTURAL LAND USE IN THE SAMARA REGION
}

\author{
Zudilin Sergey, Konakova Alyona \\ Samara State Agricultural Academy, Russia
}

\begin{abstract}
The zones of ecological trouble cover about $15 \%$ of the territory of Russia, where the main production capacities and the most productive agricultural lands are concentrated. The Samara region is characterized by a distinct natural zonality from a typical forest-steppe in the North with a forest cover close to $30 \%$, to an open dry steppe in the South with a natural forest cover of only $0.1 \ldots 0.2 \%$. The article presents an analysis of land use in the Samara region on the example of the Borsky municipal district. Research methods include environmental analysis and statistical data analysis. The article presents an analysis of the land use of the Borskiy municipal district. During zoning, the territory of the district is divided into the northern, central and southern parts. Assessment of environmental and economic parameters showed heterogeneity of the territory and the need for detailed consideration of climatic, soil, economic conditions in the design of landscape optimization systems, even in the municipal area. In general, the district's land fund experiences an average anthropogenic load, the ecological stability of the territory as a whole is characterized as unstable stable. In comparison with other areas of the Central MES, the municipal Borskiy district belongs to the category with an average ecological intensity with a stabilization index of 0.59 units due to the beneficial influence of the Buzuluksky area.

Key words: anthropogenic, influence, factor, ploughing of the territory; ecological stability of the territory
\end{abstract}

\section{Introduction}

The development of agriculture and agriculture in General puts the issues of improving the use of land resources at the forefront in the overall system of measures aimed at improving the efficiency of public production. Problem: rational use of land in a variety of forms of ownership and management of the land includes a set of measures to further intensify land use and improve soil fertility through the widespread introduction of science and best practices (Клюшин, Марин, 2011).

At present, up to 40 million hectares of arable land have been abandoned in the Russian Federation, 16 million hectares have been overgrown with bushes and trees, and 58 million have been eroded. In turn, most users want to "squeeze" the maximum profit without thinking about the consequences for the earth. The ecological trouble zones cover about $15 \%$ of the territory of Russia, where the main production facilities and the most productive agricultural land are concentrated, and most importantly, more than $60 \%$ of the population lives here (Мусаев, Шаповалов, 2016). The processes of land degradation and desertification are a serious social and environmental problem of society as a result of the irrational use of natural resources, complicated by the tension of natural factors and economic activities (Клюшин, Марин, 2011).

Rational organization of land use, soil fertility preservation and land degradation protection are impossible without proper consideration of climatic conditions of the area. For the agricultural sector, the issues of formation of the natural resource potential of the territory, their interrelation, interaction and efficiency of use are extremely important. An objective analysis of natural conditions and factors is necessary in the development of a set of measures to restore and stabilize agroecosystems.

\section{Discussions and results}

Samara region is located in the South-Eastern part of the European part of the Russian Federation in the middle reaches of Europe's largest Volga River and occupies 53.6 thousand $\mathrm{km}^{2}$, which is $0.32 \%$ of Russia's area. The territory of the region stretches from North to South for $335 \mathrm{~km}$ and from West to East for $315 \mathrm{~km}$.the region is characterized by a clearly pronounced natural zoning from the typical forest-steppe in the North with forest cover close to $30 \%$, to the open dry steppe in the South with natural forest cover of only $0.1 \ldots 0.2 \%$. Three natural-economic zones are distinguished in the region: Northern - forest-steppe, Central-transitional, southern - steppe. The Northern zone includes 8 municipal districts of the region, the Central - 12 and the southern - 7 . 
The territory of the Central natural and economic zone of the Samara region, which includes the Bor municipal district, is 25.6 thousand $\mathrm{km} 2$. The agricultural turnover includes 17.02 thousand $\mathrm{km}^{2}$, their arable land occupies 12.88 thousand $\mathrm{km}^{2}$, hayfields and pastures -3.75 thousand $\mathrm{km}^{2}$, perennial plantations -0.39 thousand $\mathrm{km}^{2}$.

The territory of the municipal district Borsky occupies the South-Eastern part of the Samara region and has an area of $2102.9 \mathrm{~km}^{2}$, of which agricultural land $-72.6 \%$, forests $-18.5 \%$, under water and swamps $1.6 \%$ of the total area of the district. The land is suitable for the cultivation of grain, fodder and vegetable crops.

Geomorphologically, the Borsky municipal district is located on the watershed of the Maly KinelChapayevka Rivers and is represented by two watersheds of the Kutuluk - Maly Kinel, Kutuluk Samara rivers, as well as floodplains and floodplains.

The territory of the region is located in the zone of moderate continental climate and belongs to the III agro-climatic region of the Samara region with low moisture. The average long-term amount of precipitation in the area is $413 \mathrm{~mm}$. the Hydrothermal coefficient of the area is 0.7-0.8 (Климат Самарской области ... 2006).

According to the natural and agricultural zoning of the Russian Federation, the Northern part of the district, located North of the Samara river, belongs to the pre - Ural province of the forest-steppe zone, the southern part of the district-to the Zavolzhsky province of the steppe zone.

The relief of the territory of Borsky municipal district is of the hilly ridge. A wide undulating plateau watersheds transform them into flat and sloping slopes. The southern slopes to the rivers Samara and Kutuluk are sloping, sometimes steep, rugged ravines and beams. The Northern slopes are flat, long, gradually passing into the floodplain terraces and floodplains. In General, the relief of the district is relatively leveled.

In the soil cover of the district, located North of the Kutuluk River, is dominated by typical chernozems, less common leached chernozems, typical carbonate and typical residual carbonate.

The Central part of the region, represented by the water divide of the rivers Samara-Kutuluk, is characterized by the greatest variety of soil differences. On the elevated parts of the relief formed and leached Chernozem typical Chernozem, typical carbonate - on undulating slopes typical of residualcarbonaceous - on steep slopes, black soil of the ordinary - on the gentle Northern slopes.

In the southern part of the area is dominated by ordinary chernozems, have a small distribution of southern chernozems.

In soil terraces dominate the black residual-Lugovaya-typical and ordinary. A large area on the terrace above the floodplain of the Samara river Sands is loosely held.

In the structure of the land fund of the Borsky municipal district, the largest share is agricultural land $72.2 \%$ and land of specially protected areas $-20.6 \%$. The share of land settlements accounted for $4.9 \%$, industrial land, transport and other special purpose $-1 \%$, forest land $-0.8 \%$. The water Fund of the district includes surface water bodies, as well as land allocated for the drainage of hydraulic and other structures necessary for the use of water bodies and is $0.4 \%$, there is no reserve land in the Bor municipal district (Отчеты о состоянии ..., 2017).

The total area of agricultural land of the district is 142274 hectares, including arable land - 107624 hectares, perennial plantations - 174 ha of the Plowed area is $52.2 \%$ of the land area, destabilizing the ecological situation, more than $70 \%$ of agricultural land (table 1 ).

The area of soil subject to water erosion in the area is 30673 hectares, which is $21.5 \%$ of the total area of agricultural land, of which poorly washed $-17 \%$, average washed $-2.3 \%$ and heavily washed $2.2 \%$.

The average humus content in the arable soil layer of the district is $4.5 \%$. Fluctuations in the boundaries of the study area are quite significant: from 3.5\% -4.0\% (southern and South-Eastern part), to 5.2-6.6\% (Northern part). The balance of humus on arable land in the district over the past decade is negative, so in 2015 it is equal to $0.07 \mathrm{t} /$ ha (Научно-производственный отчет ..., 2016).

Increased area of wetland soils that cause delay in the timely processing, 682 hectares are waterlogged, causing the impossibility of processing on 264 hectares identified again waterlogged soil (causing the inability to proceed).

Analysis of the quality of land in the Borsky district, showed the decline of fertility, large areas of land subject to degradation processes, the increase in the area of anthropogenically altered soils, indicates 
the need for certain land management activities to improve the condition and raise the level of land use.

Table 1

\begin{tabular}{|c|c|c|c|c|}
\hline \multirow[b]{3}{*}{$\begin{array}{l}\text { № } \\
\text { П.П. }\end{array}$} & \multirow[b]{3}{*}{ The type of land and categories of land } & unicipal di & Samara re & \\
\hline & & \multirow[b]{2}{*}{ Area, ha } & \multicolumn{2}{|c|}{ as a percentage } \\
\hline & & & total area & $\begin{array}{l}\text { to the area } \\
\text { of } \\
\text { agricultural } \\
\text { land }\end{array}$ \\
\hline 1 & Arable & 109712.0 & 52.2 & 71.9 \\
\hline 2 & Deposit & 7970.0 & 3.8 & 5.2 \\
\hline 3 & Perennial plantings & 174.0 & 0.1 & 0.1 \\
\hline 4 & Hayfields & 1868.0 & 0.9 & 1.2 \\
\hline 5 & Pastures & 32906.0 & 15.6 & 21.6 \\
\hline \multicolumn{2}{|c|}{ Total agricultural land } & 152630.0 & 72.6 & 100.0 \\
\hline 6 & In the stage of reclamation construction & 30.0 & 0.0 & - \\
\hline 7 & Forest & 45955.0 & 21.9 & - \\
\hline 8 & Under water & 2379.0 & 1.1 & - \\
\hline 9 & Land settlements & 562.0 & 0.3 & - \\
\hline 10 & Under roads & 3741.0 & 1.8 & - \\
\hline 11 & Swamps & 1047.0 & 0.5 & - \\
\hline 12 & Other land & 3948.0 & 1.9 & - \\
\hline \multicolumn{2}{|c|}{ Total land within the district } & 210292.0 & 100.0 & 100.0 \\
\hline
\end{tabular}

In accordance with the natural and economic conditions of the municipal district Borsky divided into three parts-the Northern (forest - steppe), Central (Buzuluk array of forest and floodplain terrace of the Samara River) and southern (steppe) (Fig. 1).

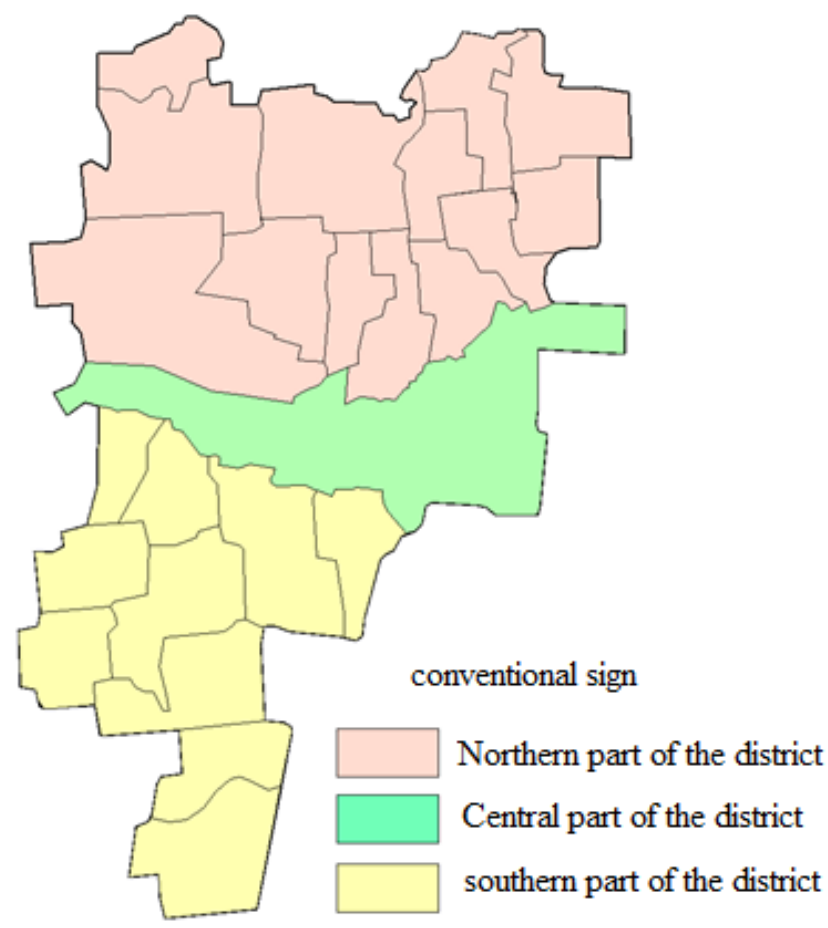

Fig. 1 Zoning of the Borsky municipal district by natural and climatic conditions 
A large proportion of the Central part of the municipal district belongs to the specially protected areas as there is an array of the national Park Buzuluk Bor. The Northern and southern part is a territory that has an agricultural orientation and is more in need of rational use and increasing the efficiency of agricultural production. The structure of the land fund of parts of the district is presented in table 2.

Table 2

The structure of the land Fund of the municipal district of Borsky on 01.01.2017 year

\begin{tabular}{|l|c|c|c|c|c|c|c|c|}
\hline \multirow{2}{*}{ Ground } & \multicolumn{2}{|c|}{ Northern part } & \multicolumn{2}{c|}{ Central part } & \multicolumn{2}{c|}{ South part } & \multicolumn{2}{c|}{ Area } \\
\cline { 2 - 10 } & hectares & $\%$ & hectares & $\%$ & hectares & $\%$ & hectare & $\%$ \\
\hline arable & 65085.0 & 63.0 & - & - & 44627.0 & 68.6 & $109,712.0$ & 52.2 \\
\hline deposit & 2384.0 & 2.1 & - & - & 5586.0 & 8.6 & 7970.0 & 3.8 \\
\hline perennials & 164.0 & 0.2 & - & - & 10.0 & 0.1 & 174.0 & 0.1 \\
\hline haymaking & 497.0 & 0.5 & 1061.0 & 2.5 & 310.0 & 0.5 & 1868.0 & 0.9 \\
\hline pastures & 14873.0 & 14.4 & 6738.0 & 16.0 & 11295.0 & 17.4 & 32906.0 & 15.6 \\
\hline $\begin{array}{l}\text { total } \\
\text { agricultural } \\
\text { land }\end{array}$ & 83003.0 & 80.6 & 7799.0 & 18.5 & 61828.0 & 95.1 & 152630.0 & 72.6 \\
\hline forests & 13029.0 & 12.6 & 26487.0 & 62.7 & 180.0 & 0.3 & 39696.0 & 18.9 \\
\hline afforestation & 1663.0 & 1.6 & 4024.0 & 9.5 & 572.0 & 0.9 & 6259.0 & 3.0 \\
\hline $\begin{array}{l}\text { under the } \\
\text { water }\end{array}$ & 1071.6 & 1.0 & 1105.4 & 2.6 & 202.0 & 0.3 & 2379.0 & 1.1 \\
\hline $\begin{array}{l}\text { land of } \\
\text { industry }\end{array}$ & 305.0 & 0.3 & 56.0 & 0.1 & 201.0 & 0.3 & 562.0 & 0.3 \\
\hline roads & 1564.0 & 1.5 & 1236.0 & 2.9 & 941.0 & 1.45 & 3741.0 & 1.8 \\
\hline marshes & 105.9 & 0.1 & 918.5 & 2.2 & 22.6 & 0.1 & 1047.0 & 0.5 \\
\hline other & 2281.0 & 2.2 & 603.0 & 1.4 & 1094.0 & 1.7 & 3978.0 & 1.9 \\
\hline in total & 103022.5 & 100 & 42228.9 & 100 & 65040.6 & 100 & 210292.0 & 100 \\
\hline
\end{tabular}

The distribution of the land fund confirms the agricultural orientation of the Northern and southern parts of the region: the share of agricultural land is $80.57 \%$ and $95.07 \%$, respectively.

Arable land in the Northern part and the southern part is 63.18 and $68.81 \%$, the grassland, represented by pastures and hayfields, in the aggregate of 14.92 and was $17.85 \%$.

The main reasons for the decrease in fertility should be called as natural factors (the presence of erosion-prone slopes, raising the level of groundwater), and the imbalance of nitrogen and other nutrients (mobile phosphorus and potassium exchange), the removal of which is not replenished by the fertilizers; reduction of crop cultivation in recent years; man-made soil pollution.

In order to organize the rational use of land in the municipal district, the formation of sustainable agricultural landscapes, the ecological and economic assessment of the district was carried out, the criteria of which are taken such indicators as ploughing of agricultural land, forest area, the coefficient of anthropogenic load, the coefficient of environmental stability, agricultural development (table.3).

The analysis of the land use structure in the municipal district of Borsky showed that the number of plowed lands per $1 \mathrm{~km}^{2}$ is $0.7 \mathrm{~km} 2$, taking into account the area occupied by Buzuluk Forest, which is a specially protected area, the ploughing area is $0.56 \mathrm{~km}^{2}$. The arable land in the Northern zone is $14 \%$ less than in the southern zone and is 0.63 and $0.77 \mathrm{~km}^{2}$ respectively.

It is established that the area belongs to the category of unstable stable, ploughing exceeds $50 \%$, forest cover reaches $22 \%$, anthropogenic load is average. Detailed consideration of the parameters of the Northern and southern part of the assessment shows strong fluctuations in the values: ploughing varies from 63 to $77 \%$, agricultural development from 72 to $94 \%$, forest area from 1 to $13 \%$. Both the Northern and southern parts of the district are ecologically unstable territories, where the coefficient of ecological stability is 0.30 and 0.23 units, respectively. 
Table 3

Parameters of ecological and economic assessment of the territory of the municipal district of Bor

\begin{tabular}{|l|c|c|c|c|c|}
\hline Territory & $\begin{array}{c}\text { Agricultural } \\
\text { development, } \%\end{array}$ & $\begin{array}{c}\text { The share of } \\
\text { tilled per 1 } \\
\mathrm{km}^{2}\end{array}$ & Wooded \% & $\begin{array}{c}\text { The coefficient } \\
\text { of } \\
\text { anthropogenic } \\
\text { load units }\end{array}$ & $\begin{array}{c}\text { The } \\
\text { coefficient of } \\
\text { ecological } \\
\text { stability, ed. }\end{array}$ \\
\hline North part & 70.51 & 0.63 & 13,80 & 2.99 & 0.30 \\
\hline South part & 93.91 & 0.77 & 1.35 & 3.37 & 0.23 \\
\hline Central part & 18.47 & 0.00 & 72.25 & 1.73 & 0.82 \\
\hline Bor district & 72.58 & 0.56 & 21.85 & 3.07 & 0.40 \\
\hline
\end{tabular}

Thus, the assessment of ecological condition of the territory of the municipal district of Borsky showed that its land Fund experiences the average anthropogenous loading, ecological stability of the territory of the area as a whole is characterized as unstable stable.

The ecological stability of the whole territory of the region is generally higher than the ecological stability of the territory occupied by agricultural land, due to the influence of the forest area Buzuluk forest.

To compare the environmental situation, the land was assessed as a natural complex with a certain natural resource potential of the territory of twelve municipal districts of the Central natural and economic zone (PEZ) of the Samara region. Depending on the proportion of the stabilizing lands for each municipal area determined by the index of stabilization (tab. 4), the value of which is determined by the environmental stress of the territory: 0.61-0.90 - weak, 0.40-0.60 - average, $0.21-0.40-$ strong, less than 0.2 - critical environmental stress (Агроэкологическая оценка земель ..., 2005).

Table 4

Status of environmental stress areas of municipal districts in Central FI Samara region

\begin{tabular}{|l|c|c|c|}
\hline \multicolumn{1}{c|}{$\begin{array}{c}\text { Municipal } \\
\text { areas }\end{array}$} & Agricultural area, ha & Stabilization index & $\begin{array}{c}\text { Category of } \\
\text { environmental } \\
\text { tension }\end{array}$ \\
\hline Bezenchuksky & 140.37 & 0.21 & strong \\
\hline Bogatovsky & 64.66 & 0.74 & poor \\
\hline Bor & 145.19 & 0.59 & medium \\
\hline Volzhsky & 152.24 & 0.34 & strong \\
\hline Kinel & 146.06 & 0.28 & strong \\
\hline Kinel-Cherkassy & 189.31 & 0.59 & strong \\
\hline Krasnoyarsk & 159.23 & 0.29 & medium \\
\hline Pohvistnevsky & 139.77 & 0.42 & poor \\
\hline Volga & 95.25 & 0.88 & poor \\
\hline Stavropol & 173.12 & 0.99 & critical \\
\hline Syzranskiy & 102.39 & 0.01 & poor \\
\hline Shigonsky & 106.57 & 0.73 & \\
\hline
\end{tabular}

In comparison with other areas of the Central PEZ, the Borsky municipal district belongs to the category with an average environmental stress - the stabilization index is 0.59 units. Large area occupied by the Buzuluk Forest has a positive impact on this criterion. That once again testifies to the beneficial effect of natural stabilizing landscapes on the ecological situation of the territory, and the destabilizing effect of intensively plowed agricultural landscapes.

On the basis of the results obtained, it can be stated that for the agricultural landscapes of the Borsky municipal district, and for the Central natural and economic zone of the Samara region, the existing organization of agricultural land does not contribute to the rational use of the natural bioenergy 
potential of the territory and it is necessary to optimize land use, changing the structure of lands and acreage in the direction of environmentally stable landscapes.

\section{Conclusions and proposals}

Large proportion of the Central part belongs to the specially protected areas. The northern and southern part is a territory that has an agricultural orientation and is more in need of rational use and increasing the efficiency of agricultural production.

The ecological stability of the whole territory of the region is generally higher than the ecological stability of the territory occupied by agricultural land, due to the influence of the forest area.

The main reasons for the decrease in fertility are natural factors - presence of erosion-prone slopes, raising level of groundwater, etc., imbalance of nitrogen and other nutrients, man-made soil pollution. In order to organize the rational use of land formation of sustainable agricultural landscapes as result of calculations can be stated that existing organization of agricultural land does not contribute to the rational use of the natural bioenergy potential of the territory and it is necessary to optimize land use, changing the structure of land.

\section{References}

1. Агроэкологическая оценка земель, проектирование адаптивно-ландшафтных систем земледелия и агротехнологий (2005) (Agroecological assessment of the land, design of adaptive-landscape farming systems and agrotechnologies) Под редакцией В.Кирюшина и А.Иванова. Москва, Росинформагротех, 784 c. (in Russian)

2. Климат Самарской области и его характеристика для климатически чувствительных отраслей экономики (2006) (The climate of the Samara region and its characteristics for climate-sensitive sectors of the economy) Приволжское УГМС, Самара, 168 c. (in Russian)

3. Клюшин П.В., Марин А.Л. Антропогенная деградация Ставропольского края (2011) (Anthropogenic degradation of the Stavropol Territory) Юг России: экология и развитие. №3. c.101-107 (in Russian)

4. Мусаев М.Р., Шаповалов Д.А., Широков В.А., Клюшин П.В. и др. Экологические проблемы земель сельскохозяйственного назначения в Северо-Кавказском федеральном округе (2016) (Environmental problems of the agricultural land in the North Caucasian Federal District) Юг России: экология и развитие. №3. с.181-192 (in Russian)

5. Научно-производственный отчет за 2015 год (2016) (Research and Production Report for 2015) ФГБУ «Станция агроимической службы «Самара», 94 с. (in Russian)

6. Отчеты о состоянии и использовании земель муниципального района Бор за 2012-2016 годы (Reports on the state and use of land for the municipal district of Bor of 2012-2016) (in Russian)

Information about authors:

Zudilin Sergey Nikolaevich, Doctor of agricultural sciences, Professor, Head of Department of Land management, soil science and agricultural chemistry, FSBEI HE Samara state agricultural Academy. 446442, Russia, Samara region, Kinel, p. g. t. Ust-kinelsky, ul. Uchebnaya, 2, 89272622382. E-mail: zudilin_sn@mail.ru Land management, crop

Konakova Alyona Y. Senior of Department of Land management, soil science and agricultural chemistry, FSBEI HE Samara state agricultural Academy. 446442, Russia, Samara region, Kinel, p. g. t. Ust-kinelsky, ul. Uchebnaya, 2, georeg.mir@yandex.ru Land management, crop 